\title{
SOUTHERN SOLUTIONS FOR WISCONSIN WOES
}

\author{
Ann C. Hodges*
}

T the first half of 2011, a number of states amended the collective bargaining laws applicable to their state and local government employees. Debate rages about whether the goal of the proponents of these changes was to address budget shortfalls or weaken labor unions, which are historically strong supporters of the Democratic Party. ${ }^{1}$ Regardless of motive, legislatures in several states accomplished the goal of severely limiting or eliminating collective bargaining for some or all public-sector employees. ${ }^{2}$ The question facing unions, employers, and employees in these states is "what now?" An answer may lie in an examination of the labor-management relationship in southern states that have historically prohibited or severely restricted bargaining. ${ }^{3}$ This article explores the

* Professor of Law, University of Richmond. I would like to thank the University of Toledo Law Review for the invitation to participate in the symposium and the participants at the symposium and those at the symposium on Public Sector Employment in Times of Crisis at the University of Richmond for insightful questions and comments on the topic, which certainly improved the article. I would also like to thank William Warwick, University of Richmond, J.D. 2012, for his valuable research and insights on the topic.

1. See Paul M. Secunda, The Wisconsin Public-Sector Labor Dispute of 2011, 27 A.B.A. J. LAB. \& EMP. L. 293, 293-94 (2012) (arguing that Republicans took advantage of the recession to enact legislation designed to reduce the power of unions); Richard Michael Fischl, "Running the Government Like a Business": Wisconsin and the Assault on Workplace Democracy, 121 YALE L.J. ONLINE 39, 59-63 (2011), available at http://www.yalelawjournal.org/2011/06/21/fischl.html (arguing that the efforts to restrict public sector bargaining are an attempt to defund unions, traditional supporters of the Democratic party, and silence the voice of working people); Joseph E. Slater, The Assault on Public Sector Collective Bargaining: Real Harms and Imaginary Benefits, AM. CONST. SOC'Y FOR LAW \& POL'Y 1 (Issue Brief, June 2011), $\mathrm{https}: / / \mathrm{www}$.acslaw.org/sites/default/files/Slater_Collective_Bargaining.pdf (arguing that the attacks on bargaining rights are not based on budget problems but instead on a desire to weaken unions, strong supporters of the Democratic Party); Chris Edwards, Challenges to U.S. Economic Recovery: Federal and State Spending, CATO INST. (Feb. 3, 2011), available at $\mathrm{http}: / /$ www.cato.org/pub_display.php?pub_id=12752 (arguing that ending public sector collective bargaining will give states more flexibility to address their long-term fiscal problems); Chris Edwards, Public Sector Unions and the Rising Costs of Employee Compensation, 30 CATO J. 87, 87-88 (2010) (arguing that state laws curing public sector unionism will lead to better fiscal policy).

2. See A. 11, 2011-12 Leg., Jan. Spec. Sess. (Wis. 2011); H. 1001, 117th Gen. Assemb., Reg. Sess. (Ind. 2011); S. 113, 107th Gen. Assemb., 1st Sess. (Tenn. 2011); H.R. 1593, 2011 Leg., 53d Sess. (Okla. 2011). The Ohio legislation, which severely restricted bargaining and eliminated bargaining rights for certain groups of employees, was overturned by referendum on November 8 , 2011. See Paul E. Kostyu, Issue 2 Rejected, Overturning SB 5, CINCINNATI.COM (Nov. 9, 2011, 12:45 AM), http://news.cincinnati.com/article/20111108/NEWS0108/111090341/Issue-2-rejectedoverturning-SB-5?odyssey=tab|topnews|text|FRONTPAGE. For the rejected legislation, see S. 5, 129th Gen. Assemb., Reg. Sess. (Ohio 2011).

3. See N.C. Gen. Stat. ANN. $\$ 95-98$ (West 2010); VA. Code AnN. $\$ 40.1-57.2$ (West 2010). 
lessons that may be learned by parties in states facing new and unfamiliar labor landscapes from the labor-relations climate in those southern states.

First, this article discusses labor relations in the southern states, with a primary emphasis on Virginia, and analyzes the factors that contribute to successful union-management relations where they exist in these states. Then, this article considers how these factors might apply in the states that have recently enacted changes to their collective bargaining laws, focusing specifically on those states that eliminated or virtually eliminated bargaining rights. Finally, this article concludes that while labor relations might change in those states, unionization will continue as employees seek a voice in the workplace.

\section{LABOR RELATIONS WITHOUT LAW}

Labor laws in the public sector came late to the party. ${ }^{4}$ Wisconsinironically - passed the first U.S public sector collective bargaining law in 1959. ${ }^{5}$ That same year, North Carolina outlawed public sector collective bargaining as a result of an effort by the Teamsters Union to organize police officers in the city of Charlotte. ${ }^{6}$ However, even in absence of formal enabling legislation, unionization occurred prior to enactment of the prohibition. ${ }^{7}$ Virginia's publicsector employees were also becoming increasingly unionized throughout the 1960s and 1970s, until the Virginia Supreme Court held that localities had no authority to bargain. ${ }^{8}$ Not content with a Supreme Court prohibition, Virginia followed the decision with a statutory prohibition on collective bargaining in 1993. ${ }^{9}$ Texas similarly prohibited bargaining for all public employees, except for police and fire employees at local option. ${ }^{18}$ While collective bargaining is not expressly banned for all employees in other southern states, bargaining is limited in many of these states by the absence of any law compelling employers to deal with unions representing their employees. ${ }^{11}$ Indeed, unionization rates in both the public and private sectors in these states are among the lowest in the nation. ${ }^{12}$

4. See generally JosePh E. SLATER, PUblic WORKERS: GOVERNMENT EMPLOYEe UNIONS, THE LAW AND THE STATE 1900-1962 (2004).

5. Martin H. Malin et al., Public Sector Employment: Cases and Materials 227 (2d ed. 2011).

6. See Jason Burton \& David Zonderman, Where Did This Law Come From? A History of General Statute 95-98, at 2-13, available at $\mathrm{http} / /$ nchope.org/adobe/GS9598history.pdf; Michael G. Okun, Public Employee Bargaining in North Carolina: From Paternalism to Confusion, 59 N.C. L. REV. $214,218-20(1980)$. The statute does not expressly outlaw bargaining but rather collective bargaining agreements. Id. at 225 .

7. Burton \& Zonderman, supra note 6, at 3-13.

8. Virginia v. Cnty. Bd. of Arlington Cnty., 232 S.E.2d 30, 33, 44-45 (Va. 1977).

9. See VA. CODE ANN. § 40.1-57.2 (West 2010).

10. See TeX. Gov't COdE ANN. $\$ 617.002$ (West 2010); TeX. Loc. Gov't Code ANN. $\S 174.023$ (West 2010).

11. Richard C. Kearney \& David G. Carnevale, Labor Relations in the Public Sector 60-68 (3d ed. 2001).

12. Data from BARRY T. HIRSCH \& DAVID A. MACPHERSON, UNION MEMBERSHIP AND EARNINGS DATA BOoK 32-37 (2011). The data in this volume are taken from the Current Population Survey, a monthly survey of wage and salary workers conducted by the Census Bureau. 


\begin{tabular}{|l|c|c|c|c|c|c|}
\hline \multicolumn{1}{|c|}{ State } & $\begin{array}{c}\text { Private } \\
\text { sector } \\
\text { member- } \\
\text { ship }\end{array}$ & $\begin{array}{c}\text { Private } \\
\text { sector } \\
\text { contract } \\
\text { coverage }\end{array}$ & $\begin{array}{c}\text { Member- } \\
\text { ship Rank } \\
\text { among } \\
\text { states** }\end{array}$ & $\begin{array}{c}\text { Public } \\
\text { Sector } \\
\text { membership }\end{array}$ & $\begin{array}{c}\text { Public } \\
\text { sector } \\
\text { contract } \\
\text { coverage }\end{array}$ & $\begin{array}{c}\text { Membership } \\
\text { Rank among } \\
\text { states for all } \\
\text { workers*** }\end{array}$ \\
\hline Alabama & $5.7 \%$ & $6.2 \%$ & 26 & $28.9 \%$ & $32.3 \%$ & 27 \\
\hline Georgia & $2.5 \%$ & $3.0 \%$ & 48 & $11.1 \%$ & $14.5 \%$ & 49 \\
\hline Louisiana & $3.2 \%$ & $4.1 \%$ & 42 & $9.3 \%$ & $11.7 \%$ & 48 \\
\hline Mississippi & $3.7 \%$ & $4.2 \%$ & 37 & $7.4 \%$ & $11.2 \%$ & 47 \\
\hline $\begin{array}{l}\text { North } \\
\text { Carolina }\end{array}$ & $1.8 \%$ & $2.5 \%$ & 51 & $9.5 \%$ & $15.7 \%$ & 51 \\
\hline $\begin{array}{l}\text { South } \\
\text { Carolina }\end{array}$ & $2.7 \%$ & $4.0 \%$ & 45 & $13.1 \%$ & $16.3 \%$ & 45 \\
\hline Texas* & $3.2 \%$ & $4.0 \%$ & 41 & $16.9 \%$ & $21.0 \%$ & 43 \\
\hline Virginia & $2.9 \%$ & $3.3 \%$ & 44 & $10.8 \%$ & $14.4 \%$ & 46 \\
\hline
\end{tabular}

*Texas allows collective bargaining for police and firefighters at local option

**Includes the District of Columbia

***Percentage of union members among public and private sector workers

Despite the legal obstacles, unions are active in the public sector in all southern states; such unions have had some notable successes in forging strong and healthy relationships with employers in order to effectively represent their employee members. ${ }^{13}$ In the absence of collective bargaining, unions commonly use lobbying and political activity at both state and local levels to achieve their goals. ${ }^{14}$ However, political power comes only with resources, including both members who speak out politically, vote, and volunteer in election campaigns, and also the finances to support the candidates and engage in lobbying campaigns. In order to lobby successfully, unions must build and retain their membership levels, for without strong support, lobbying will be ineffective. Unions also must have the resources to communicate with their membership in order to support and encourage their political activism. To build membership,

$I d$. at 1 . Thus, the questions regarding union membership and coverage by a union contract are based on employee self-reporting, and an estimate is made based on the sample. Id at 1-7. For information about the sampling methods and the reliability of the data, see U.S. BUREAU OF LABOR StaTISTICS, Household Data, EMPloyment AND EARNINGS (Feb. 2006), at 193-98, available at http://www.bls.gov/cps/eetech_methods.pdf. The data on public sector union membership and coverage includes federal-sector workers, as well as state and local government workers. In states with a heavy presence of federal-sector workers, their presence will affect any inferences drawn relating to the relationship of state and local government bargaining laws and union membership. Because of its proximity to Washington and its large number of military installations, Virginia has an especially large number of federal-sector employees. See DIRECTORY OF U.S. LABOR ORGANIZATIONS 149-51 (Court Gifford ed., 2011) (listing nearly 100 local unions in Virginia that are clearly composed of federal workers).

13. Ann C. Hodges, Lessons from the Laboratory: The Polar Opposites on the Public Sector Labor Law Spectrum, 18 CORNELl J.L. \& PUB. POL'Y 735, 765 (2009).

14. Id. at 749-50. See also Ann C. Hodges \& William Warwick, The Sheathed Sword: Public Sector Union Efficacy in Non-Bargaining States, 27 A.B.A. J. LAB. \& EMP. L. 275, 279-80 (2012). For a recent example, see VA. EDUC. Ass'N, Lee County EA "Buttons Down" a Win, http://www.veanea.org/home/1646.htm (last visited Mar. 30, 2012) (describing a successful campaign to reverse a school board decision to convert 37 probationary teachers to long term substitutes with no benefits). 
unions in non-bargaining states must organize constantly. ${ }^{15}$ In bargaining states, intensive organizing often ends with a representation election, or at least once the union obtains a collective bargaining agreement. This is particularly true if the union is able to negotiate a fair-share agreement requiring all bargaining unit members to pay the costs of representation. ${ }^{16}$ In non-bargaining states, there is no respite from the organizing campaign, for there is no ability to require payment of dues. $^{17}$

To organize successfully in non-bargaining states, unions must constantly demonstrate the benefits of unionization to employees. For example, unions can represent their members in legal and administrative proceedings. Because most government employees can appeal adverse personnel actions by virtue of their civil service protection or tenure, access to free or low cost representation in such procedures is a valuable benefit for union members. Civil service and tenure carry with them the constitutional requirement of due process before termination. ${ }^{18}$ Further, most states have some form of appeal process for other disciplinary actions as well, and many civil service systems allow for challenges to job classification or other actions. ${ }^{19}$ For example, Virginia mandates grievance procedures for employees of the state and larger local government units. ${ }^{20}$ And while some states are eliminating tenure for teachers, ${ }^{21}$ the majority of states still

15. Hodges, supra note 13 , at 751 ; Hodges \& Warwick, supra note 14 , at 288.

16. A fair-share agreement requires all the employees in the bargaining unit to contribute to the costs of union representation. MALIN ET AL., supra note 5, at 751. Many public sector bargaining laws permit unions and employers to negotiate fair-share agreements. Id. Such agreements can compel the employees to pay only the costs of collective bargaining and related activities and cannot mandate payments for political activities. Abood v. Detroit Bd. of Educ., 431 U.S. 209, 235-36 (1977).

17. Hodges \& Warwick, supra note 14 , at $279-80$.

18. Cleveland Bd. of Educ. v. Loudermill, 470 U.S. 532, 538-48 (1985).

19. See Stephen L. Hayford \& Richard Pegnetter, Grievance Adjudication for Public Employees: A Comparison of Rights Arbitration and Civil Service Appeals Procedures, 35 ARB. J. 22, 25 (1980); MALIN ET AL., supra note 5, at 136-40. A few states have eliminated or broadly reformed civil service in ways that limit employee rights and therefore, opportunities for unions to provide assistance to employees. See generally Jonathan Walters, Life After Civil Service Reform: The Texas, Georgia and Florida Experiences, GoverNING, Oct. 2002, available at http://www.businessofgovernment.org/sites/default/files/LIfeAfterCivilServiceReform.pdf (discussing the effects of civil service reform in Texas, Georgia, and Florida, and the potential impact of this reform and future reform endeavors in other states). Notably, Arizona just enacted legislation making all new hires and some current employees at will, removing them from the civil service system. Arizona Employees to Be 'At Will' Under New Law, 60 Gov'T EMP. REL. REP. (BNA) 511 (May 15, 2011).

20. VA. CODE ANN. $\S \S 15.2-1506$ to -1507 (West 2010); VA. CODE ANN. $\S \S 2.2-3000,3003-$ 3006 (West 2010). See also S.C. CODE ANN. $\S \S 8-17-310$ to -360 (2011) (containing grievance procedure for South Carolina state employees); TEX. Gov'T CODE ANN. $\S 617.002$ (West 2010) (preserving the right of public employees to present grievances through a representative that does not claim the right to strike).

21. Kathy Christie \& Jennifer Dounay Zinth, Teacher Tenure or Continuing Contract Laws, EDUC. COMM'N OF THE STATES 1 (Aug. 2011), available at http://www.ecs.org/clearinghouse/ 94/93/9493.pdf. Notably, the Wisconsin statute effectively eliminated tenure for teachers because tenure was available only if collectively bargained, and collective bargaining is now restricted to wages. See WIS. STAT. ANN. $§ 111.70(4)(\mathrm{mb})$ (West 2010) (limiting bargaining to wages only); 
have some form of job protection for most teachers. ${ }^{22}$ In addition, many states are revising and enhancing their evaluation systems for teachers. ${ }^{23}$ Access to representation and support in such procedures, whether by union representatives or lawyers, is a benefit which in most cases, far outweighs the cost of membership. ${ }^{24}$ And where there is no exclusive representation, these benefits can be provided to dues paying members only, with no concerns about any duty owed to the nonmembers. Some unions provide legal representation in other proceedings as well, both those related to the job $\mathrm{b}^{25}$ and those unrelated, such as real estate closings or divorce proceedings. ${ }^{26}$

In addition to legal and professional representation, unions in nonbargaining states provide other benefits to members as well. Many unions provide additional education and training for their members. For example, teachers' unions provide continuing education to both new and veteran teachers, ${ }^{27}$ while correctional officers' unions provide training in self-defense and conflict resolution. $^{28}$ Unions also provide product discounts of various sorts, some directly related to the workplace, and others general benefits such as insurance or credit cards. ${ }^{29}$ These additional benefits entice some prospective members, who may then see the other benefits of unionization as well.

Unions also engage in activities that directly benefit the community and enhance their image among prospective members, employers, and the general public, who may then support union initiatives using the ballot box or contacts with members of school boards and city councils. ${ }^{30}$ Such activities are

WIS. STAT. ANN. $\$ 118.22$ (West 2010); David J. Strom \& Stephanie S. Baxter, From the Statehouse to the Schoolhouse: How Legislatures and Courts Shaped Labor Relations or Public Education Employees During the Last Decade, 30 J.L. \& Educ. 275, 298 (2001).

22. Christie \& Zinth, supra note 21 , at 1.

23. Id.

24. Texas courts recently held that public employees without bargaining rights have a statutory right to union representation at an investigatory interview that might lead to discipline. See City of Round Rock v. Rodriguez, 317 S.W.3d 871, 882-91 (Tex. App. 2010). This right, analogous to the federal private-sector Weingarten right, provides another vehicle for unions to add value to employees. See NLRB v. Weingarten, 420 U.S. 251, 256-68 (1975). The Texas court found this right was incorporated in the statutory right to union representation, even where the employee and union had no right to collective bargaining. Rodriguez, 317 S.W.3d at 882-91. This decision provides an example of how unions in non-bargaining states creatively utilize existing laws and regulations to benefit employees.

25. VEA Legal Services: Your Safety Net, VA. EDUC. Ass'N, http://www.veanea.org/home/ legal-services.htm (last visited Oct. 25, 2011).

26. Id.

27. Hodges \& Warwick, supra note 14, at 282. For example, the VEA website provides resources for new teachers, existing teachers, and parents. See In the Classroom, VA. EduC. Ass'N, http://www.veanea.org/ (last visited Nov. 3, 2011); Parent Resources, VA. Educ. Ass'N, http://www.veanea.org/(last visited Nov. 3, 2011).

28. Am. Fed'n of State, CNTy., \& Mun. Emps., AFl-Cio, Preventing Workplace VIOLENCE: A UNION REPRESENTATIVE'S GUIDEBOOK 31 (2d ed. 2006).

29. See Benefits, STATE EMPS. ASs'N OF N.C., http://www.seanc.org/membership/benefits.aspx (last visited Oct. 17, 2011).

30. Hodges, supra note 13 , at $750-51$. 
particularly important in southern states, where hostility toward unionization is longstanding and widespread. ${ }^{31}$

In addition to convincing employees that union membership is worthwhile, unions in non-bargaining states must convince employers to deal with unions. There are two primary ways to accomplish this. The first is through sheer political power. ${ }^{32}$ As noted, unions support political candidates and lobby elected officials. ${ }^{33}$ Union political power is easier to exercise at the local level with school boards, city councils and county boards, for each voice carries more weight in an election or jurisdiction with fewer active voters. ${ }^{34}$ A large union within a small political community will have strong political leverage simply based upon voting power, even though that union is in a non-bargaining state.

The second method of convincing employers to deal with unions is demonstrating to employers the benefits of doing so. Unions can add value to government employers in a number of ways. They can lobby not only for benefits for employees, but also for issues that benefit employers, such as funding for schools, law enforcement or fire protection, or legislation that assists in fighting crime or enhancing public education. ${ }^{35}$ Unions engage in research that can both support these lobbying efforts and provide valuable information to the employer. ${ }^{36}$ Further, the training offered to union members benefits employers by providing more qualified employees without cost to the governmental unit.

In many jurisdictions, employers and public sector unions have worked together to provide benefits to the governmental entity and the public it serves. For example, the Norfolk Federation of Teachers and the Norfolk Public Schools have collaborated for many years to improve both student achievement and teacher quality. ${ }^{37}$ The school district values the union's input and commitment and works closely with the union despite the absence of any legal obligation to do so. ${ }^{38}$ This collaborative relationship led to the district's receipt of the Broad

31. Kearney \& CARnEVAle, supra note 11 , at 9-33, 65, 73-74. For a nuanced discussion of the source and the role of anti-union sentiment in the South, see Stephen Amberg, Governing Labor in Modernizing Texas, 28 Soc. SCI. HIsT. 145-88 (2004).

32. Union support for Governor Beverly Perdue's campaign in North Carolina led to an Executive Order providing workplace access for unions and opportunities to meet and confer with state government officials. See Randy Hagler, Executive Order Gives Labor Groups Access, BLUENOTE (Fraternal Order of Police, N.C.), Mar./Apr. 2010, at 5, available at $\mathrm{http}: / / \mathrm{www}$.ncfop.org/ht/a/GetDocumentAction/i/1613. See also infra notes $125-131$ and accompanying text.

33. Hodges, supra note 13 , at $749-50$.

34. Id.

35. Hodges \& Warwick, supra note 14 , at 280.

36. Id. at 280-81.

37. Saul A. Rubinstenn \& John E. McCarthy, Collaborating on School Reform: Creating Union-Management Partnerships to Improve Public School Systems 18-20 (2010).

38. Id. at 19 . 
Prize for best urban school district. ${ }^{39}$ The Norfolk teachers and district, like other unions and employers in non-bargaining states, have negotiated memoranda of understanding which, while not legally binding, are voluntarily complied with because of the benefits that arise from the agreement for the employer, the union, and its members. ${ }^{40}$

Another important component to successful labor relations in nonbargaining states is the ability to collect dues from members. As noted, unions must be able to demonstrate substantial membership to accomplish their goals. ${ }^{41}$ But along with substantial membership must come the financial resources provided by union dues. Resources are essential to provide the benefits of unionization, as well as to continue the constant organizational process. In both Virginia and North Carolina, payroll deduction of dues is permissible, easing the task of collecting membership dues. North Carolina authorizes payroll deduction of dues if an organization has at least 2,000 members with 500 from the public sector. ${ }^{42}$ In addition, local government units can agree to deduct dues for smaller organizations. $^{43}$ In Virginia, there is no express statutory authorization of dues deduction, but the General Assembly rejected a bill to prohibit it. ${ }^{44}$ Thus, at least at present, Virginia's governmental units can agree to payroll deduction for union dues. $^{45}$ Furthermore, if they allow deductions for one organization of employees but deny payroll deduction to others, they must have a constitutional basis for differential treatment. $^{46}$

Despite this less-than-dismal picture, impediments to successful labor relations exist in the southern states. Constant organizing utilizes resources that could be devoted to other purposes. ${ }^{47}$ While organizing should never be put on

39. Press Release, The Broad Foundation, \$1 Million Broad Prize for Urban Education Awarded to Norfolk Public Schools, Four Finalist Districts (Sept. 20, 2005), available at http://www.broadprize.org/news/320.html.

40. RUBINSTEIN \& MCCARTHY, supra note 37, at 20. See also KEARNEY \& CARNEVALE, supra note 11 , at 66 (discussing negotiations between unions and employers in the public sector in North Carolina, South Carolina, and Texas); Hodges \& Warwick, supra note 14, at 286; Michael G. Okun, Public Employee Bargaining in North Carolina: From Paternalism to Confusion, 59 N.C. L. REV. 214, 228 (1980); Memphis AFSCME Local 1733, Memorandums of Understanding, $\mathrm{http} / /$ www.afscmelocal 1733 .org/index.cfm?action=cat\&categoryID=7b40d851-709d-4771-98a9e2c8c92aab64 (last visited Jan. 5, 2012) (listing existence of memoranda of understanding with the city).

41. See supra text accompanying note 14 .

42. N.C. GEN. STAT. ANN. § 143B-426.40A(g) (West 2011). This statute was amended by the North Carolina legislature in January 2012 to remove the authority of local boards of education to deduct union dues but a temporary restraining order prevented the amendment from taking effect, as the court concluded that it was likely unconstitutional. Andrew Ballard, North Carolina Court Temporarily Blocks Ban on Teachers' Association Dues Deduction, 6 DAILY LAB. REP. (BNA) A-9 (Jan. 10, 2012).

43. N.C. GEN. Stat. ANN. § 143B-426.40A(g).

44. S. 963,1993 Leg. (Va. 1993) (failed by a 21-19 floor vote).

45. 1992 Va. Op. Att'y Gen. 126 (1992), available at 1992 WL 533106, at*1. See also Commonwealth v. City of Richmond, No. G 5072-2, 1981 WL 180567, at *9 (Va. Cir. 1981) (upholding city's right to enact an ordinance allowing deduction of membership dues).

46. 1992 Va. Op. Att'y Gen., 1992 WL 533106, at *3.

47. Hodges \& Warwick, supra note 14 , at 289. 
the back burner as even committed union members need to be reminded of the purpose and benefits of unionization, the respite that comes with negotiating a binding contract allows unions in bargaining states time to focus on other priorities. ${ }^{48}$ Unions in non-bargaining states can never achieve that respite and without significant membership, they are relatively powerless. And the hostile climate for unions in the South makes organizing particularly difficult. ${ }^{49}$

Additionally, employers who choose not to deal with a union need not. Without a desire on both sides to work together, it will not happen. Absent sufficient political power to compel reluctant employers to deal with them, unions must be careful to maintain healthy and positive relationships with employers, lest they doom any effort to work with them. Pushing too far too quickly can set back the relationship. Unions must be very careful if they choose a position adversarial to an employer, for fear that they may impair their ability to obtain benefits for their membership. Unions in bargaining states can choose the most effective method of advocacy and can shift from a cooperative relationship to an adversarial one as needed, for the employer must deal with the union chosen by a majority of employees. ${ }^{50}$ Without bargaining rights, unions in non-bargaining states must be far more cautious in choosing the adversarial course. And without the adversarial option, union successes may come more slowly, in turn making it more difficult to retain membership. Further, the union may lose its ability to obtain benefits for its members despite all of its efforts as a result of a mere change in employer officials, from one who sees value in cooperating with the union to one who does not. ${ }^{51}$ Stability in leadership on both sides contributes to positive labor relations as the parties are able to build trust and develop positive working relationships. ${ }^{52}$

Yet another possible impediment to union success, or even effectiveness, is dues collection. Where union dues deduction is permissible by law, ${ }^{53}$ employers that see the benefits of unions may be willing to agree to payroll deduction. This will make it easier for the union to collect dues and therefore, easier to provide value to union members. In the absence of dues deduction, however, the union must spend resources collecting dues that could otherwise be devoted to representation. Any loss of dues further impairs representational functions. Substantial losses may lead to a downward spiral for the union as limited resources lead to fewer successes, which lead to additional losses of membership.

48. Id.

49. Recent research shows that the presence of a right-to-work law is a significant determinant of the level of unionization in the public sector. See Raymond Hogler \& Christine Henle, The Attack on Public Sector Unions in the United States: How Regional Culture Influences Legal Policy, 62 LAB. L.J. 135, 138, 143 (2011). Right-to-work states are generally in the South and Southwest. Id. at 137-38.

50. Hodges \& Warwick, supra note 14 , at $287-88$.

51. Id. at 288 .

52. RUBINSTEIN \& MCCARTHY, supra note 37 , at 20 (noting the importance of stability of union leadership and a supportive board of education to the successful collaborative partnership of the Norfolk Federation of Teachers and Norfolk Public Schools); Hodges, supra note 13, at 752-53; Hodges \& Warwick, supra note 14 , at 288.

53. See, e.g., 1992 Va. Op. Atty. Gen. 126, available at 1992 WL 533106, at *1. 
Having reviewed the operation of labor relations in states without bargaining laws, I now turn to the question of whether labor relations in states with new bargaining restrictions may follow the southern pattern.

\section{ApPlication OF the SOUTHERN STRategy to STATES WITH NEWLY ENACTED BARGAINING RESTRICTIONS}

\section{A. The Legal Changes}

How might the strategies used by unions in the southern non-bargaining states apply in states like Wisconsin that have newly enacted bargaining restrictions? A brief review of the recent changes in law will reveal the similarities and differences between the laws in these states. ${ }^{54}$ Two states have recently repealed collective bargaining laws: Oklahoma and Tennessee. ${ }^{55}$ The Oklahoma law eliminated mandatory bargaining for employees of large municipalities, except for police and firefighters who were covered by a different statute, and left the choice of whether to bargain to the municipality's discretion. $^{56}$ The Tennessee law eliminated mandatory bargaining for teachers and replaced it with a system of "collaborative conferencing" which is required, but does not involve majority union representation and leaves the employer free to act unilaterally if no agreement is reached. ${ }^{57}$

Legislation in Wisconsin prohibited bargaining for certain categories of employees. ${ }^{58}$ For employees other than law enforcement and firefighters, Wisconsin limits bargaining to wages and provides only a small range for that

54. Laws eliminating collective bargaining for public employees are not just recent phenomena. Both Virginia and North Carolina at one time allowed bargaining. Further, states without bargaining laws may have executive orders or local ordinances that allow bargaining, but that may be withdrawn or amended with political changes. For example, Indiana state employees lost the right to bargain in 2005 when Governor Mitch Daniels was elected and reversed an existing executive order authorizing bargaining. Steven Greenhouse, In Indiana, Clues to Future of Wisconsin Labor, N.Y. TIMES, Feb. 26, 2011, at A1, available at http://www.nytimes.com/2011/ 02/27/business/27collective-bargain.html?pagewanted=all.

55. Martin H. Malin, The Upheaval in Public Sector Labor Law: A Search for Common Elements, 27 A.B.A. J. LAB. \& EMP. L.149, 154-55 (2012).

56. Id. See also H.R. 1593, 53d Leg., 2011 Sess. (Okla. 2011).

57. See TENN. CODE ANN. § 49-5-601 (West 2011). As noted by Professor Malin, it remains to be seen how closely this process will resemble collective bargaining. Malin, supra note 55, at 155 . Several lawsuits that have been filed suggest that at least some employers may be resistant to working with unions under the new law. See infra note 91.

58. Wisconsin eliminated bargaining rights for university faculty and staff, home health care workers, family child care workers, and employees of the University of Wisconsin hospital and clinics. See WIS. Stat. AnN. $\S 111.81(7)$ (West 2011) (redefining "employee" to omit the mentioned groups). In the recently overturned S.B. 5 legislation, Ohio eliminated bargaining rights for university faculty, certain employees of police and fire departments (by broadening the definition of supervisor), and employees of community schools, and made bargaining optional for certain public employers including conversion community schools, regional governmental authorities and employers of specified unclassified civil service employees. See S. 5, 129th Gen. Assemb., Reg. Sess. (Ohio 2011). 
negotiation. ${ }^{59}$ With this severe restriction of bargaining subjects, Wisconsin has effectively eliminated collective bargaining for most employees. The recent decision of the largest unions representing state employees not to seek recertification as employee representatives under this new statute cements the consequences of the law. ${ }^{60}$

\section{B. The Impact on Membership}

It seems likely that unions in states that have outlawed or effectively outlawed collective bargaining will see some drop in membership. Data suggests this occurred both in Virginia and Indiana when employees lost the right to bargain. ${ }^{61}$ Indeed, public sector union membership in the non-bargaining states has long been lower than in bargaining states, ${ }^{62}$ although it is difficult to know how much of that difference is attributable to the fact these states are also southern, right-to-work states where private sector union membership is low as well. ${ }^{63}$ In states that had fair-share provisions in the bargaining law, ${ }^{64}$ it seems certain that at least some employees who were compelled to support the union by such agreements will not do so when the requirement is lifted. Thus, initially unions will almost certainly confront some loss of membership and thus loss of resources. ${ }^{65}$

59. Wis. STAT. ANN. § $111.91(3)$. Pursuant to a legal challenge filed by unions, the restriction on bargaining was recently upheld, but the provision eliminating dues deduction and the provision requiring annual recertification of labor unions were found unconstitutional. See Wisconsin Educ. Ass'n Council v. Walker, 824 F. Supp. 2d 856, 876 (W.D. Wis. Mar. 30, 2012). An appeal has been filed with the U.S. Court of Appeals for the Seventh Circuit. Michael Bologna, Wisconsin Attorney General Seeks Halt To Ruling for Collective Bargaining Rights, 69 DaILY LAB. REP. (BNA) A-5 (Apr. 10, 2012). A request for a stay pending appeal was denied. See Wisconsin Educ. Ass'n Council v. Walker, No. 11-cv-428-wme (W.D. Wis. Apr. 27, 2012).

60. Scott Bauer, Scott Walker's Collective Bargaining Law Keeping Wisconsin Unions From Seeking Recertification, HuFFINGTON Post (Sept. 22, 2011, 5:55 PM), http://www.huffingtonpost. com/2011/09/22/scott-walker-collective-bargaining_n_976376.html.

61. Lon S. Felker et al., Public Sector Unionization in the South: An Agenda for Research, in 13 J. COllective Negotiations Pub. SeCtor 1, 9 (1984); Greenhouse, supra note 54.

62. See HIRSCH \& MACPHERSON, supra note 12, at 32-37 (noting public sector membership rates of $9.5 \%$ and $10.8 \%$ in North Carolina and Virginia respectively-the two states that completely outlaw bargaining - and, for example, rates of $56.6 \%$ in California, $50.2 \%$ in Illinois, $31.1 \%$ in Iowa, $23.3 \%$ in Florida, $59.0 \%$ in New Jersey, and $41.4 \%$ in Montana representing states that participate in public sector bargaining).

63. See id. The lower percentage of union members in Florida, however, suggests that being a right-to-work state in the South depresses membership even in a state with a collective bargaining law and a constitutional right to bargain collectively. Fla. CONST. art. I, § 6; FLA. STAT. ANN. $\S 447.201-09$ (West 2001).

64. Both Wisconsin and Ohio had fair-share provisions in prior law that were eliminated by the 2011 changes, although as noted earlier, Ohio's law was recently overturned by referendum. For the changes, see WIS. STAT. ANN. $\S 111.70(2)$ (West 2011) (barring fair share for general municipal employees but allowing for public safety employees pursuant to a referendum); 2011 WIS. Act 10, $\S 198$, amending WIS. STAT. ANN. $\S 111.06(\mathrm{c})(1)$ (West 2011) (eliminating authorization for fairshare agreements); OHIO REV. CODE ANN. $\$ 4117.09$ (C) (West 2010).

65. Notably, the Wisconsin Education Association Council laid off $40 \%$ of its staff after the recall elections failed to replace enough senators to overturn the bargaining bill. Wisconsin 
On the other hand, there is some reason to believe that the loss of membership will not reduce unions to the membership levels in the southern states. States like Wisconsin have a long tradition of unionization ${ }^{66}$ and a relatively high level of union membership in the private sector. ${ }^{67}$ Faculty in Wisconsin voted to unionize even after enactment of the law banning bargaining for university faculty. ${ }^{68}$ In addition, the enactment of the bargaining reform laws was accompanied by substantial activism on the part of union members and their supporters. This was followed by political mobilization for recall elections in Wisconsin ${ }^{69}$ and a successful referendum to overturn the bill in Ohio. ${ }^{70}$ While there may be some letdown in Wisconsin as a result of the failed attempt to recall enough members of the legislature to overturn the law, the activism generated, along with partial success, may prevent a large reduction in union support.

In Tennessee and Oklahoma, the tradition of unionism is not as strong. ${ }^{71}$ Both are right-to-work states. ${ }^{72}$ Both states had higher public sector union memberships prior to the elimination of collective bargaining than did the nonbargaining states, however. ${ }^{73}$ There may be reason to expect that the drop in membership in those states will not be dramatic, however. In Tennessee, the

Teachers Union Issues Layoff Notices to 40\% of Employees, HUFFINGTON POST (Oct. 16, 201 1, 6:12 AM ET), http://www.huffingtonpost.com/2011/08/16/wisconsin-teachers-union-_0_n 928152.html. Six new positions were created, however. Deborah Ziff \& Stephen Verburg, Teachers Union Layoffs Could Be Bellwether for Other Public Employee Unions, WIS. ST. J. (Aug. 16, 2011, 10:30 AM), http:/host.madison.com/wsj/news/local/education/article_6ee3fl58-c7a0$11 \mathrm{e} 0$-aba0-001cc4c002e0.html. AFSCME Council 40, which represents 32,000 local government workers in Wisconsin, is leaving seven of 38 staff positions vacant. Id.

66. See supra note 5 and accompanying text. See also JoHn E. Gotherman et al., OHIO MUNICIPAL LAW $\S 11.2$ (1st ed.) (describing labor relations in Ohio prior to the 1984 collective bargaining statute).

67. In 2010, Ohio and Wisconsin ranked 5th and 13th respectively among the states in the number of all wage and salary workers who were union members and 18 th and 17 th respectively in the percentage of workers unionized. HIRSCH \& MACPHERSON, supra note 12, at 30-31. North Carolina and Virginia ranked 51st and 46th respectively in the percentage of workers unionized. Id.

68. Mark Niquette, Wisconsin's Professors Unionize in Defiance of Walker's Law, BLOOMBERG NEws, Mar. 31, 2011, http://www.bloomberg.com/news/2011-03-31/wisconsinprofessors-unionize-defy-walker-s-law-on-collective-bargaining.html.

69. Monica Davey \& A.G. Sulzberger, Wisconsin Curbs Public Unions, But Democrats Predict Backlash, N.Y. TIMES, Mar. 11, 2011, at A1.

70. Jim Siegel, Want to Talk? Only After SB5 Is Repealed Opponents Say, ColumBuS DISPATCH, Aug. 19, 2011, http://www.dispatch.com/content/stories/local/2011/08/19/want-to-talkonly-after-sb-5-repeal.html.

71. For example, Tennessee ranked 28th in the number of union members and 44th in the percentage of union membership in 2010. HIRSCH \& MACPHERSON, supra note 12, at 31. Oklahoma ranked 33rd in the number of members and 42nd in the percentage of union membership. Id.

72. See TENN. Code ANN. § 50-1-201 (West 2011); OKLA. Const. art. II, § 2 (2011). See also supra note 49 (noting the negative association between right-to-work status and union density).

73. HIRSCH \& MACPHERSON, supra note 12, at 35-37 (showing the following union membership rates in 2010: North Carolina, 9.5\%; Oklahoma, 13.2\%; Tennessee, 17.6\%; and Virginia, $10.8 \%$ ). 
only employees who lost bargaining rights were teachers. ${ }^{74}$ Teachers have a long tradition of membership in professional associations which, as collective bargaining in the public sector evolved, became unions. ${ }^{75}$ Education is the most unionized sector in the workforce, public and private. ${ }^{76}$ In addition, National Education Association (NEA) affiliates typically provide professional liability insurance and other legal assistance to their members, which is a valuable benefit of employment. ${ }^{77}$ In Oklahoma, the only employees covered by the statute were in large cities. This may lead to a smaller reduction in membership as urban employees are more likely to join unions than employees in small towns and rural areas. ${ }^{78}$ Thus, there may be some ability to retain membership in Oklahoma as well.

\section{Using the Southern Model to Retain the Power to Effectively Represent Employees}

\section{The Key Elements of the Strategy}

As in non-bargaining states, organizing will become a constant activity for unions newly deprived of bargaining rights. Organizing must be internal as well as external-to both retain existing members and attain new ones. The unions simply must engage their membership actively to demonstrate the desirability of unionization. As noted, the activism generated by the demonstrations and political fights in Wisconsin and Ohio provides a base for building a comprehensive and continual organizing campaign. ${ }^{79}$ While less widely publicized, teachers in Tennessee and workers in Oklahoma also mobilized against the legislation eliminating bargaining and making other changes affecting public employees. ${ }^{80}$ If the unions can successfully maintain a sufficient

74. See S. 113, 107th Gen. Assemb., 1st Sess. (Tenn. 2011). Other public employees in Tennessee had no statutory bargaining rights.

75. MALIN ET AL., supra note 5, at 164, 229-30.

76. Press Release, U.S. Dep't of Labor, Union Members-2010 (Jan. 21, 2011), available at http://www.bls.gov/news.release/pdf/union2.pdf. The National Education Association is the largest union in the United States. DiRECTORY OF U.S. LABOR ORGANIZATIONS, supra note 12, at 3.

77. See Liability Insurance for Educators, NEA MEMBER BENEFITS (Nov. 10, 2009), http://www.neamb.com/xchg/neamb/xsl/hs.xsl/-/home/1212_1840.htm\#; Legal, TENN. EDUC. Ass'N, http://www.teateachers.org/legal (last visited Nov. 11, 2011).

78. See Hodges, supra note 13 , at 754; KEARNEY \& CARNEVALE, supra note 11 , at 28-29 (noting correlation of unionization with urbanization).

79. See supra notes $69-70$ and accompanying text.

80. See Blake Farmer, Tennessee Teachers Join Battle Against Anti-Union Bills (National Public Radio broadcast Mar. 8, 2011), available at http://www.npr.org/ 2011/03/08/134358759/tenn-teachers-join-battle-against-anti-union-bills; Sanford Myers, Teachers Rally at TN Capitol, TENNESSEAN, Mar. 6, 2011, http://www.tennessean.com/ apps/pbcs.dll/gallery?Site $=$ DN\&Date $=20110306 \&$ Category $=$ NEWS01 \&ArtNo $=103060805 \&$ Ref $=$ PH (describing rally by 3000 to protest changes in teacher collective bargaining law); Tim Talley, Okla. Firefighters Oppose Proposed Pension Changes, Bloomberg BUs. WK., Mar. 9, 2011, http://www.businessweek.com/ap/financialnews/D9LRVM781.htm (describing firefighters protest against pension changes); Julia Edwards, Union Protests Spread Across the U.S., NAT'L J., Apr. 8, 
membership base to have the resources and political clout to lobby effectively and to provide representational benefits to union members, they can continue to build their power even without bargaining rights.

Laws banning payroll deduction of dues present a potential problem with maintaining significant membership. In North Carolina and Virginia, no currently effective laws ban dues deduction, and thus there is at least the potential to obtain an agreement to deduct union dues. And in North Carolina, the law expressly allows employees to authorize dues deduction for 'employees' associations" that meet certain requirements relating to the size of the membership. ${ }^{81}$ The new Wisconsin law, on the other hand, expressly bans payroll deduction of union dues. ${ }^{82}$ The Tennessee law, by contrast, allows collaborative conferencing over payroll deduction. ${ }^{83}$ Oklahoma does not appear to ban payroll deduction of union dues for municipal employees. ${ }^{84}$

Thus, while some employees whose bargaining rights were eliminated retain the ability to obtain payroll deduction of dues through lobbying or negotiation, Wisconsin employees have no such option unless the unions are successful in their legal challenge to the provision. For Wisconsin unions, collection of dues from those remaining members may become a significant administrative problem that drains resources from the unions, impairing their ability to effectively represent their members. ${ }^{85}$ These unions will need to quickly determine an effective method for dues collection, perhaps an authorization for recurring charges to credit cards or bank accounts.

\section{Strategies for Teachers, Firefighters and Law Enforcement}

In Virginia, the unions that have most successfully navigated the shoals created by the absence of the right to bargain are in education and firefighting. ${ }^{86}$

2011, http://nationaljournal.com/union-protests-spread-across-the-u-s--20110408 (describing protests in both Tennessee and Oklahoma).

81. N.C. Gen. STAT. ANN. $§ 143 B-426.40 A(g)$ (West 2010).

82. WIS. STAT. ANN. $\S \S 111.70(3 \mathrm{~g}), 111.845$ (West 2010). The provision eliminating dues deduction was found unconstitutional on March 30,2012. See supra note 59.

83. Andy Sher, Teacher Union Bargaining Replaced by 'Conferencing', TIMES FREE PRESS (Chattanooga, Tenn.), May 21, 2011, http://www.timesfreepress.com/news/2011/may/21/teacherunion-bargaining-replaced-conferencing/. If there is no agreement in collaborative conferencing, however, the school board sets the terms and conditions of employment. TENN. CODE ANN. § 49-5609(d) (West 2010). Dues deduction is unlikely to be implemented unilaterally by employers; and because both individual employees and employee organizations have representation in the collaborative conferencing process, it may be harder to reach agreement on that subject. See infra note 93 and accompanying text.

84. Mary Ellen Flannery, Oklahoma! Where Educators Have a Voice, NEATODAY, Mar. 22, 2011, http://neatoday.org/2011/03/22/oklahoma-where-educators-still-have-a-voice/.

85. Some unions have existing contracts with dues deduction provisions. Ziff \& Verburg, supra note 65 . The law barring dues deduction does not take effect until these contracts expire, thus providing the affected unions time to explore and implement an alternative method of dues collection.

86. Hodges, supra note 13 , at 753 . Unionization has been less successful in law enforcement. Id. at n.127. 
The long tradition of associational membership followed by the transition to unionization in those fields is likely one reason why these Virginia unions have been successful. ${ }^{87}$ The parent unions have substantial resources. ${ }^{88}$ Additionally the members are bound together by a shared profession creating common interests that can help transcend issues and efforts that divide the membership. These unions can more easily demonstrate their benefits to employers and employees by providing targeted training to members. Political activity is easier at the local level as well, where activist unions can support candidates for school board and city council, races that require fewer resources and fewer votes to influence the outcome. Effective campaign activity provides influence that can effectuate policies favorable to union goals, which demonstrates the value of the union to both employees and employers. Many important decisions regarding educational employees and firefighters are made at the local level and thus, are subject to union influence.

The political influence of unions is extremely important. For example, the fact that firefighters have not had their bargaining rights eliminated in any state demonstrates their political influence at the state level. ${ }^{89}$ Similarly, police officers retained their bargaining rights in all the states that made changes in 2011. Interestingly, however, police unions have been less successful in Virginia than unions in firefighting and education. ${ }^{90}$ That Tennessee teachers obtained bargaining rights in a right-to-work state where bargaining for all other employees is banned, demonstrates their political clout. Yet they were unable to beat back the changes in the law in 2011, and lawsuits filed by unions demonstrate that at least some school districts are taking advantage of the law to attempt to escape the influence of unions. ${ }^{91}$ Based on the success of education

87. Id. at 753; KEARNEY \& CARNEVALE, supra note 11 , at $34-35,38,41$.

88. LM-2s for the following unions show that the NEA had $\$ 216,941,792$ in assets in 2010. National Education Association, in U.S. DEP'T OF LABOR, FORM LM-2 LABOR ORGANIZATION ANNUAL REPORT (2012), available at http://jasonahart.com/misc-uploads/NEA-HQ-2010Report.pdf. The AFT had $\$ 93,109,861$ in 2011. American Federation of Teachers, in U.S. DEP'T OF LABOR, FORM LM-2 LABOR ORGANIZATION ANNUAL REPORT (2011), available at http://kcerds.dol-esa.gov/query/org-Report.do. The IAFF, with a much smaller membership, had $\$ 29,210,699$, in 2010. International Association of Firefighters, in U.S. DEP'T OF LABOR, FORM LM-2 LABOR ORGANIZATION ANNUAL REPORT (2010), available at http://kcerds.dolesa.gov/query/org-Report.do.

89. The subjects over which bargaining is permitted have been limited for police officers and firefighters in some states, however. See OHIO REV. CODE ANN. § 4117.08(B) (West 2010) (overturned by referendum); 2011 N.J. LAws c.78 §40c (limiting bargaining over health care benefits); 2011 Mass. Acts ch. 69, $\S 3(\mathrm{c})$ (authorizing changes in health insurance benefits despite contrary provisions in collective bargaining agreements after negotiation with a committee composed of union and retiree representatives).

90. Hodges, supra note 13, at 753.

91. See Matthew Stewart, Judge Hears Blount Teachers' Union Claim, DaILY TIMEs (Blount County, Tenn.), Oct. 18, 2011, http://www.thedailytimes.com/Local_News/story/Judge-hearsBlount-teachers-union-claim-id-016822 (describing a lawsuit by the Blount County Education Association against Blount County Schools based in part on the school district's refusal to negotiate with union and arguing that the school district relied on a retroactive application of the new Tennessee statute to defend its actions). See also First Amended Complaint, Sumner Cnty. Educ. 
unions in North Carolina and Virginia, however, it seems likely that the unions will retain some membership and power in that state. ${ }^{92}$ The unknown factor is the impact of the collaborative conferencing regime. This regime seems designed to divide and conquer, as it requires representation for any organization supported by at least $15 \%$ of the employees, as well as representation for unaffiliated employees if at least $15 \%$ of the employees vote to be unaffiliated. ${ }^{93}$ This structure may result in competition between unions that may ultimately be destructive to union representation. Unions in Virginia have generally avoided inter-union competition to prevent the diversion of scarce resources that are needed for representation purposes. ${ }^{94}$ Given the history of exclusive union representation, however, unions in Tennessee may be able to avert these divisive battles if the unions seek collaborative conferencing in districts with a history of representation and eschew those where another union has such a history. ${ }^{95}$

Based on the southern experience, one might conclude that Wisconsin teachers may have greater success in maintaining membership and successful relationships with employers than other groups of employees in that state. Events in Wisconsin provide further support for this hypothesis. During the legislative process, the Wisconsin Association of School Boards indicated serious

Ass'n v. Sumner Cnty. Bd. of Educ., No. 3:11-cv-00848 (M.D. Tenn. Sept. 29, 2011) (alleging denial of rights under the Professional Educators' Collaborative Conferencing Act).

92. The Tennessee Education Association web site claims a membership of 52,000, although that includes support personnel, students, higher education faculty and others who were not eligible to bargain before the new statute was passed and are not covered by the collaborative conferencing bill. See TENN. CODE ANN. $\S \S 49-5-601,-602$ (West 2011); Membership, TENNESSEE EdUC. Ass'N, http://www.teateachers.org/membership (last visited Oct. 13, 2011).

93. TENN. CODE ANN. § 49-5-605.

94. Interview with Rob Jones, Dir. of Gov't Relations, Former President, Va. Educ. Ass'n, in Richmond, Va. (June 26, 2011); Interview with Brian Dawe, Executive Dir., Am. Corr. Officer Intelligence Network, in Richmond, Va. (Mar. 16, 2011). While most other developed countries have systems in which unions represent only their membership, in the United States, exclusive representation has been the model in the private sector and generally, after some experimentation with other models, in the public sector as well. MALIN ET AL., supra note 5, at 340. Recently, several Missouri school districts attempted to implement bargaining systems that did not involve exclusive representation. These systems were challenged with mixed success by unions as inconsistent with Missouri's constitutional requirement of collective bargaining. See Bayless Educ. Ass'n v. Bayless Sch. Dist., No. 09SL-CC01481 (Mo. Cir. Ct. Feb. 10, 2010) (striking down a system of representation by two individual representatives elected by the employees and a representative designated by the union with the largest employee membership as collaborative bargaining, not the constitutionally required collective bargaining); Springfield Nat'l Educ. Ass'n v. Springfield Bd. of Educ., No. 0931-CV80322 (Mo. Cir. Ct. Sept. 10, 2009) (upholding system that allowed representation by one union or multiple unions regardless of the desires of the unions involved). Data from the 1990s regarding union representation elections in the public sector demonstrated a relatively high number of elections involving competing unions, which drains resources without adding significantly to overall union membership. KATE BRONFENBRENNER \&

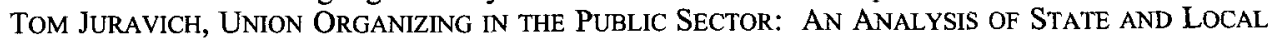
ELECTIONS 122 (1995). On the other hand one might argue that union competition is beneficial for employees, offering a choice of unions and perhaps increasing the quality of representation.

95. Information available on the internet suggests that the Tennessee Education Association has much larger membership in the state than the Tennessee Federation of Teachers, which does not appear to have its own web site. See Membership, supra note 92 and accompanying text. 
concern about the impact of a bill severely curtailing collective bargaining. ${ }^{96}$ After the bill's enactment, a number of education employers negotiated agreements with their unions prior to the effective date of the law to delay its implementation. ${ }^{97}$ Despite these positive signs, continual organizing will be essential to maintain membership and sufficient clout to influence employers to deal with the unions.

\section{Strategies for General Municipal and State Employees}

Unionization among general municipal employees (other than firefighters, police officers, and teachers) and state employees has proved more difficult in Virginia, with its absence of legal protection. ${ }^{98}$ There is neither a long tradition of association membership among these groups nor the cohesion of a shared profession. ${ }^{99}$ While some municipal employees bargained prior to $1977,{ }^{100}$ there was no tradition of bargaining on the part of state employees. However, one group of state employees has had some success in unionizing: corrections officers. ${ }^{101}$ This group is closely aligned with other law enforcement that shares a dangerous profession. As a result, the union can provide training benefits as well as specific lobbying support to the employer. ${ }^{102}$

96. See David Lewin et al., GetTing It Right: EMPIRICAL EVIDENCE and Policy IMPLICATIONS FROM RESEARCH ON PUBLIC-SECTOR UNIONISM AND COLLECTIVE BARGAINING 20 (2011), available at http://www.employmentpolicy.org/sites/www.employmentpolicy.org/ files/EPRN $\% 20$ PS $\% 20$ draft $\% 203 \% 2016 \% 2011 \% 20$ PM $\% 20$ FINALtk-m14\%20edits.pdf; Letter from Wisconsin Ass'n of Sch. Bds. to The Honorable Alberta Darling \& The Honorable Robin Vos (Feb. 15, 2011) (copy on file with the author).

97. LEWIN ET AL., supra note 96, at 20.

98. Research on public sector organizing in states with collective bargaining laws demonstrates that most elections take place in smaller units and in education and law enforcement, rather than in larger state and general municipal units. See BRONFENBRENNER \& JURAVICH, supra note 94, at 122.

99. The Virginia Governmental Employees Association is the exception to the general lack of association membership. See Accomplishments, VA. GOVERNMENTAL EMPS. Ass'N, $\mathrm{http}: / / \mathrm{www} . v g e a .0 r g / \mathrm{i} 4 \mathrm{a} /$ pages/index.cfm?pageid=3284 (last visited Oct. 28, 2011). It has focused on legislative goals relating to state employees' pay and benefits and boasts of accomplishments in those areas. See id. It affirmatively disclaims union status, however. See infra note 131.

100. See Virginia v. Cnty. Bd. of Arlington Co., 232 S.E.2d 30, 33 (Va. 1977) (noting that Arlington County had collective bargaining agreements with firefighters, teachers, nonprofessional school employees, school administrators and all other county employees at the time of the lawsuit); COMmonWealth OF VA., Rights OF PUBliC EMPLOYEes, REPORT OF THE STUDY COMMISSION, H.R. No. 28, at 6 (1974) (describing collective bargaining agreements covering, inter alia, county workers and sanitation employees).

101. Hodges, supra note 13, at 749 n.99; Hodges \& Warwick, supra note 14 , at 284 . The Virginia Governmental Employees Association is a longstanding association that engages in lobbying on behalf of state employees. Representing the Commonwealth's Employees and Retirees: The VGEA Works for You!, VA. GOVERNMENTAL EMPS. ASs'N, http://www.vgea.org/i4a/pages/index.cfm?pageid=1 (last visited Mar. 12, 2012). The organization has thousands of state employee members, but specifically disclaims being a union. Id. Associational lobbying can be an effective tool to address wage and benefit issues at the state level, however. See id:; 52 Years of Accomplishments, VA. GovernMENTAL EMPS. Ass'N, http://www.vgea.org/i4a/pages/index.cfm?pageid=3284 (last visited Mar. 12, 2012).

102. Hodges \& Warwick, supra note 14, at 282. 
What does this suggest for Wisconsin's state and local government employees and Oklahoma's municipal employees? It will probably be more difficult for these unions to maintain union membership and relationships with employers, at least initially. The tradition of bargaining may help to retain membership, but the general employee bargaining units, particularly the larger units, may lack the cohesiveness of a common profession or job and regular contact among bargaining unit employees that encourage continued membership. ${ }^{103}$ As noted above, continued and intensive organizing will be essential to maintenance of membership.

Research indicates that union tactics are extremely important to successful organizing. ${ }^{104}$ The use of "grassroots union-building" strategies is strongly correlated with union organizing success in both the public and private sectors. ${ }^{105}$ Historically, public sector unions in states with bargaining laws have not often faced strong employer opposition. ${ }^{106}$ As a result, the unions were not often required or motivated to use intensive organizing tactics. ${ }^{107}$ Times have changed, however, necessitating changes in strategy. Public employees, and in particular unionized public employees and their unions, have been identified in many states as the source of budget crises. ${ }^{108}$ Regardless of the merits of that position, ${ }^{109}$ some public employers and their constituents subscribe to this view. Accordingly and responsively, unions must mobilize their members, using more aggressive tactics to overcome this view.

Tactics that form a part of "grassroots union-building" include "person-toperson contact, rank-and-file leadership development and escalating internal and external pressure tactics." 110 Union members need to be actively involved in leadership roles, conducting small group meetings with other union members and

103. Unionization is generally higher in local government than in state government, perhaps reflecting the greater ease of organizing smaller and more cohesive bargaining units. See Union Affiliation of Employed Wage and Salary Workers by Occupation and Industry, BUREAU OF LABOR STATISTICS, U.S. DEP'T OF LABOR (Jan. 21, 2011), available at http://www.bls.gov/ news.release/union2.t03.htm; BRONFENBRENNER \& JURAVICH, supra note 94, at 5-6.

104. TOM JURAVICH \& KATE BRONFENBRENNER, Preparing for the Worst: Organizing and Staying Organized in the Public Sector, in ORganizING To WIN: NEW ReSEarch ON UNION STRATEGIES 262, 269 (Kate Bronfenbrenner et al. eds., 1998). Notably, Juravich and Bronfenbrenner recognized the threat to public sector unions.long before 2011. Id. at 263.

105. Id at 269-78.

106. $I d$.

107. Id. Bronfenbrenner \& Juravich indicate that the CWA has used the intensive organizing model successfully to organize state and local government workers in the hostile state of Texas. BRONFENBRENNER \& JURAVICH, supra note 94, at 122.

108. Michael Powell, Public Workers Face Outrage as Budget Crises Grow, N.Y. TIMES, Jan. 2, 2011, at A1, http://www.nytimes.com/2011/01/02/business/02showdown.html?pagewanted=all.

109. See Catherine Fisk \& Brian Olney, Labor and the States' Fiscal Problems: Not the Problem But Perhaps Part of the Solution, in When STATES Go Broke: OrIGINS, ConteXt AND SOLUTIONS FOR THE AMERICAN STATES IN FISCAL CRISIS (Conti-Brown \& Skeel eds., forthcoming Cambridge Univ. Press 2012) (discussing data that establish the lack of connection between collective bargaining and state budget issues). See generally LEWIN ET AL., supra note 96 (discussing data relating to public employee compensation and public sector collective bargaining and recommending retaining and updating public sector collective bargaining).

110. JURAVICH \& BRONFENBRENNER, supra note 104, at 269. 
actively participating in events such as solidarity days, rallies, and job actions. ${ }^{111}$ Development of coalitions with community groups is another effective grassroots tactic. ${ }^{112}$ Use of these strategies, as well as efforts to develop opportunities for members to become social friends with common interests, can help build and maintain the union as a community, which may be particularly important where the members do not share other commonalities such as a profession or shared ethnic identity. ${ }^{113}$ Opportunities to develop closer connections among members could include social and sports activities, discussion groups, family events, classes, or community-service activities. ${ }^{114}$

These comprehensive campaign tactics build solidarity among union members, attract community support for the union, and demonstrate to the employer the power of the union members. The union's representation activities are also important in organizing. ${ }^{115}$ Thus, even where the union does not retain the right to bargain, it must maintain its workplace presence with active union stewards, regular membership meetings, regular communication with members, and assistance in any available grievance, civil service, or tenure proceedings. ${ }^{116}$ Union successes and benefits should be widely publicized. ${ }^{117}$ As noted previously, worker mobilization in opposition to the legal reforms provides a base to begin this effort, and in Wisconsin, this activism continued during the recall elections. The current effort to recall Governor Walker will continue the momentum, but the unions must take care that the political campaign does not overtake the internal organizing needed to maintain membership. ${ }^{118}$ Of course all of these efforts utilize union resources, and without fair share, those resources will almost certainly be less than in the past.

The goal of organizing in a non-bargaining state is to attain and maintain sufficient membership to support efforts to encourage employers to deal voluntarily with unions in the absence of any legal requirement to do so. Simultaneously with organizing members, unions must develop relationships with other organizations to support their political efforts and utilize their pooled resources to provide benefits to both members and employers. Almost certainly

111. Id. Solidarity days and job actions can be simple, such as everyone wearing the same color on a particular day or gathering in front of the building before work and walking in together, or more complex, such as taking down from the classroom all items paid for by the teachers. See Hodges, supra note 13, at 750. For another effective example, see the action described in Lee County EA Buttons Down a Win, supra note 14, regarding the Lee County Education Association's efforts using a button campaign to reverse a school board action converting probationary teachers to long term contract status.

112. JURAVICH \& BRONFENBRENNER, supra note 104, at 269.

113. See Dan Cornfield et al., In the Community or in the Union? The Impact of Community Involvement on Nonunion Worker Attitudes about Unionizing, in ORGANIZING TO WIN: NEW RESEARCH ON UNION STRATEGIES, supra note 104, at 245, 256-57.

114. Id. See also supra notes 28-30 and accompanying text.

115. JURAVICH \& BRONFENBRENNER, supra note 104, at 276.

116. See id.

117. See id.

118. See Recall Walker Efforts, SCOTT WALKER WATCH, http://scottwalkerwatch.com/signrecall-petition/recall-walker-efforts/ (last visited Nov. 7, 2011). 
the unions (or their national affiliates) are already engaged in research to support legislative initiatives and training of employees (and in the case of education, constituent groups such as parents). These benefits to employers must be highlighted and leveraged to obtain employer cooperation. Where positive and trusting relationships with employers do not exist, they must be developed. This may require a change in union strategies in some jurisdictions. Adversarial relationships most often result in roadblocks to union goals without legal bargaining rights. ${ }^{119}$ Cooperative efforts can start small, with informal nonbinding agreements on issues of importance to the employer and the union. As trust develops, more comprehensive agreements may follow. ${ }^{120}$ If unions are unable to build such relationships, membership may suffer, as accomplishments on behalf of the membership help to sustain it.

In Oklahoma, employers can still voluntarily negotiate binding collective bargaining agreements with unions. ${ }^{121}$ Where strong relationships already exist, unions may be able to reach such agreements. In Wisconsin, the emphasis must be on informal nonbinding agreements that provide sufficient benefits to both parties to induce voluntary compliance.

Regardless of the level of active union membership, it seems unlikely that Governor Walker's government will be responsive to dealing with unions, given its role in the legislation that removed union rights and the resulting battles between the Governor and his supporters and the unions. This may compound the difficulties of retaining membership at the state level. But unions may be able to work with individual agencies to improve workplace conditions for their members. In Virginia, the union representing correctional officers has been able to work with individual wardens in prisons to reach nonbinding agreements relating to workplace safety, despite the absence of widespread unionization at the state level. ${ }^{122}$

Moreover, in contrast to Virginia, North Carolina state employees have succeeded in obtaining both legislation and executive orders benefitting public sector unions. North Carolina Governor Beverly Perdue issued an executive order providing unions with workplace access to employees for recruiting and educational purposes. ${ }^{123}$ The order also provides unions that satisfy defined membership requirements with the right to meet and confer with the Governor,

119. KEARNEY \& CARNEVALE, supra note 11 , at 341.

120. Developing cooperative relationships in environments with a history of adversarial relations is easier said than done and will take time. Id. at 341 . Unions face a difficult task of keeping membership commitment while developing a positive relationship with management. Without commitment from employers, it will not happen. However, it has been done in the past, even in states without bargaining. See RubINSTEIN \& MCCARThY, supra note 37, at 18-20. See also KEARNEY \& CARNEVALE, supra note 11, at 341.

121. See supra note 56 and accompanying text.

122. Hodges \& Warwick, supra note 14 , at 287.

123. N.C. Exec. Order No. 45, § 1(a) (Jan. 21, 2010), available at $\mathrm{http} / / / \mathrm{www}$.governor.state.nc.us/newsItems/ExecutiveOrderDetail.aspx?newsItemID $=884$. The previous governor, Mike Easley, also issued an executive order providing some rights to employee organizations, although it was not as expansive as the current order. See Hagler, supra note 32, at 5. 
the Director of Personnel, and agency personnel. ${ }^{124}$ Additionally, the order encourages independent state agencies such as higher education systems to follow the order. ${ }^{125}$ Legislatively, union supporters achieved enactment of a statute authorizing payroll deduction of union dues. ${ }^{126}$ The State Employees Association of North Carolina ("SEANC") 127 highlights many other legislative victories on its web site. ${ }^{128}$ Other organizations representing state employees also benefit from these provisions. ${ }^{129}$ Labor unions have also convinced the International Labor Organization to find that North Carolina and thus, the United States, is violating international law by prohibiting the fundamental right of collective bargaining for its public employees. ${ }^{130}$ The successes of the SEANC, which unlike the Virginia Governmental Employees Association proudly claims to be a union, ${ }^{131}$ may in part be attributable to the affiliation with the Service Employees International Union, a large and successful traditional labor union. ${ }^{132}$ Whatever the cause, these achievements of North Carolina public-sector unions demonstrate what can be accomplished at the state level, even without bargaining.

While Wisconsin's state leadership is currently hostile, that was certainly true in North Carolina at one time as well. Additionally, despite the more dramatic financial problems in North Carolina, as contrasted with Wisconsin, ${ }^{133}$ the unions in 2011 managed to prevent furloughs, pay cuts, and devastating

124. N.C. Exec. Order No. $45, \S 2(\mathrm{a})$.

125. Id. §6.

126. See supra note 42 and accompanying text.

127. The Association boasts over 55,000 members. Welcome, StATE EMPS. Ass'N OF N.C., http://www.seanc.org/about/ (last visited Oct. 17, 2011).

128. Legislative Victories, STATE EMPS. ASS'N OF N.C., http://www.seanc.org/legislative/ victories.aspx (last visited Oct. 17, 2011).

129. See Hagler, supra note 32, at 5.

130. See Andrew M. Ballard, Union Files Complaint with ILO Alleging State Violates International Labor Law, 238 DAILY LAB. REP. (BNA) A-3 (Dec. 13, 2005); Andrew M. Ballard, ILO Recommendation Seen Aiding Push to Allow N.C. Public Employees Bargaining, 64 DaILY LAB. REP. (BNA) A-1 (Apr. 4, 2007).

131. Compare FAQs: Membership, STATE EMPS. Ass'N OF N.C., http://www.seanc.org/quicklinks/faq.aspx (last visited Oct. 17, 2011) (stating SEANC has been unionized since 2008), with Home, VA. GOVERNMENTAL EMPS. ASs'N, http://www.vgea.org/i4a/ pages/index.cfm?pageid=1 (last visited Oct. 17, 2011) ("VGEA is not a union ....").

132. See Compare FAQs: Membership, supra note 131.

133. Compare The Trillion Dollar Gap State Fact Sheets-North Carolina, PEW CENTER ON THE STATES, available at http://www.pewcenteronthestates.org/uploadedFiles/wwwpewcenteronthe statesorg/Initiatives/R_and_D/Trillion_Dollar_Gap_factsheets_NorthCarolina.pdf (last visited Nov. 11,2011 ) (showing North Carolina's pension liability is well-funded but retiree health insurance benefits are not), with The Trillion Dollar Gap: State Fact Sheets-Wisconsin, PEW CENTER ON THE STATES, available at http://www.pewcenteronthestates.org/uploadedFiles/wwwpewcenteronthe statesorg/Initiatives/R and_D/Trillion_Dollar_Gap_factsheets_Wisconsin.pdf (last visited Nov. 11, 2011) (showing that $\bar{W}$ isconsin is a national leader in funding both pension liabilities and other benefit liabilities). See also Joseph A. McCartin, What's Really Going on in Wisconsin?, New REPUBLIC, Feb. 19, 2011, available at http://www.tnr.com/article/politics/83829/wisconsin-publicemployees-walker-negotiate?page $=0,1$ (noting that Wisconsin and Ohio's budgets were in much better shape than North Carolina's at the time of the proposed collective bargaining restrictions). 
changes in their health insurance plan. ${ }^{134}$ Thus, continued organizational efforts and political mobilization may turn the tide for the state employees in Wisconsin as well. If North Carolina unions can achieve success in the strong anti-union environment that exists there, unions in Wisconsin, with its long tradition of unionization and bargaining, should have an easier road.

\section{4. $\quad$ Finding the Silver Lining}

There is even one possible advantage of the absence of a standard collective bargaining statute: the lack of a legal regime that tracks unions and employers into traditional bargaining, focused only on terms and conditions of employment narrowly writ. ${ }^{135}$ By defining certain issues as mandatory bargaining subjects, collective bargaining laws may discourage negotiation over broader issues impacting both labor and management, as well as the public, such as educational policy, privatization of public services, or allocation of law enforcement resources. ${ }^{136}$ Additionally, the fear of binding collective bargaining agreements on subjects otherwise reserved to management may discourage employers from risking negotiations with a legally imposed exclusive representative. While the parties in bargaining states would certainly be free to discuss non-mandatory bargaining subjects and even to embody agreements in a nonbinding memorandum of understanding, the potential for misunderstanding and confusion may dissuade the parties from engaging in such discussions. The hostility manifested in the recent efforts to alter collective bargaining statutes may dim the possibilities of such discussions under the new regimes. Yet if government units and unions can move past these divisions, the absence of legal restrictions on bargaining may offer an opportunity for them to risk discussions that may lead to collaborative efforts that address some of the troubling issues facing state and local governments, such as educational failure, crime, and poverty, as well as improvements in customer service, productivity, and cost savings. ${ }^{137}$ Some employers and unions in non-bargaining states have succeeded in such efforts. ${ }^{138}$ Achievement of such a goal, however, will require a level of trust and statesmanship not evident in the revisions of collective bargaining laws to date.

134. Legislative Victories, supra note 128.

135. See Martin H. Malin, The Paradox of Public Sector Law, 84 IND. L.J. 1369, 1389-90 (2009).

136. See id. at 1389-91.

137. See id. at 1391-97.

138. See supra notes $37-40$ and accompanying text. For a blueprint for achieving a new labormanagement relations system in a state that has not made major revisions to its collective bargaining laws to date, see BARRY BluEstone \& ThOMAS A. KOCHAN, Boston Foundation, TOWARD A NEW Grand BARGaIn: COllaborative APPROACHES TO LABOR-MANAGEMENT REFORM IN MASSACHUSETTS 6-8 (2011), available at http:/www.employmentpolicy.org/sites/www.employ mentpolicy.org/files/field-content-file/pdf/Mike\%20Lillich/GrandBargain\%20Report_3.pdf. 


\section{CONCLUSION}

Collective bargaining for public employees took a series of body blows in the spring of 2011 , with state legislation outlawing and severely restricting bargaining. Almost certainly some drop in public sector union membership will result, but the events of 2011 will not be a deathblow for unionization in the public sector. States in the South, with hostile political and legal climates, have demonstrated that public sector unions can and will survive, while providing benefits to workers despite such obstacles. As Michael Duff has stated, "The labor movement was created not by statutes, but by workers and their unions."139 Public sector workers in bargaining states, like private sector workers and public sector workers in non-bargaining states before them, are discovering the "smash mouth truth.",140 Workers and their unions must be willing "to fight ... against long odds," 141 to organize, "to create tumult in the workplace,",42 and to use creative tactics to achieve their goals. And they will. Labor unions may be down, but they will not go away. ${ }^{13}$ So long as there are workers and employers, there will be unions, for the contest over allocation of resources as between capital and labor, or taxpayers and the employees who provide their services, is eternal. The possibility that the attacks on public employees and their unions may lead to a new regime where unions and government employers collaborate on issues far beyond traditional bread and butter is enticing. Whether government officials and union leaders can and will take the risks required to create a new model of labor relations, however, remains to be seen.

139. Michael C. Duff, of Courage, Tumult, and the Smash Mouth Truth: A Union Side Apologia, 15 EMP. RTS. \& EMP. POL'Y J. 521, 536 (2011).

140. Id. at 527.

141. Id. at 543 .

142. Id. at 540 .

143. See Richard B. Freeman, Through Public Sector Eyes: Employee Attitudes Toward Public Sector Labor Relations in the U.S., in PUBLIC SeCtor EMPLOYMENT IN a Time of TRANSITION 59, 60, $71-72$ (Dale Belman et al. eds., 1996) (showing 39\% of nonunion public sector workers surveyed would vote for union representation). 